\title{
In Pursuit of Ecological Forestry: Historical Barriers and Ecosystem Implications
}

\author{
James M. Gresh* and Jason R. Courter \\ Department of Natural Sciences, Malone University, Canton, OH, United States
}

The global need for ecological forestry is more important today than ever. But despite a century of technical advancements from forestry leaders-especially in North America and Europe-the world's forest ecosystem is declining at a time when carbon levels are rising, and biodiversity is at risk. Unfortunately, even the world's innovation leaders are struggling to change industry practices in their home countries. Undeterred by the lack of progress, new efforts are being attempted with Europe taking a markedly different path than the U.S. In the U.S., the pursuit of ecological forestry has embraced natural

OPEN ACCESS

Edited by:

Christopher Michael Gough, Virginia Commonwealth University,

United States

Reviewed by:

John Schelhas,

United States Forest Service (USDA),

United States

Dan Kneeshaw,

Université du Québec à

Montréal, Canada

*Correspondence:

James M. Gresh

jmgresh1@malone.edu

Specialty section:

This article was submitted to

Forest Disturbance,

a section of the journal

Frontiers in Forests and Global

Change

Received: 10 June 2020

Accepted: 07 January 2021

Published: 27 January 2021

Citation:

Gresh JM and Courter JR (2021) In

Pursuit of Ecological Forestry:

Historical Barriers and Ecosystem

Implications.

Front. For. Glob. Change 4:571438.

doi: 10.3389/ffgc.2021.571438 disturbance frameworks and stresses customized goals for local environments and social demands. In Europe, a broad application of low-intensity harvest protocols and canopy protection is being promoted for many forest types. The U.S. approach shows strong ecological promise at local and regional scales, but its broad adoption within the industry as a whole is limited and inconsistent. For the European approach, the broadly elevated priority of continuous canopy draws scientific critics, but their forestry industry is adopting and applying the concept. Although lower-intensity harvests are common to both regions, evidence suggests that Europe may be using low-intensity methods too broadly, while the U.S. is using them too little. The objective of this perspective is to describe the historical development of ecological forestry in Europe and the United States, and to propose research adjustments to help America pursue broader ecological forestry application. By understanding the historical precedents that influence forestry perceptions and the differences in contemporary approaches among forestry leaders, forestry scientists may be better equipped to design research and promote practices that can influence industry behavior for better ecosystem implications.

Keywords: carbon sequestration, continuous canopy cover, ecological forestry, forest biodiversity, forest regeneration, "close-to-nature" forestry, old growth

\section{INTRODUCTION}

The ecological care of forests has been an elusive goal for humanity. Beginning well before historical records were kept, global deforestation has persisted leaving devastating images of massive clear-cuts from the 1700-1800's. Despite scientific advances and government regulation, deforestation continued with the period of 1980-1995 sustaining the highest global deforestation rate in history (Williams, 2006). Around the time of this peak deforestation, the U.S. and Europe improved their terrestrial ecosystems to become carbon sinks (Houghton et al., 1983; Houghton, 2003) even while increasing 
consumption of wood products in these regions. Unfortunately, their consumption growth was satisfied with increased imports sourced, in part, from ecologically destructive harvests elsewhere. Today, the pace of deforestation is slowing, but global forest management practices continue to cause declines in biodiversity and reductions in carbon stocks at a time when carbon levels are rising, and biodiversity is at risk (Lindenmayer et al., 2012; Franklin et al., 2018).

Encouragingly, the science of ecological forestry continues to advance and innovate-especially with alternative silvicultural approaches developed in North America and Europe that attempt to address concerns about ecosystem impact from intensive forestry (Puettmann et al., 2015). But even the innovative leaders are struggling to achieve ecosystem changes and the adoption of ecological practices in their home countries. According to the United Nations Food and Agricultural Organization (FAO), 73\% of European forests are structurally even-aged and 55\% are $<80$ years old, which is indicative of industrial forests with reduced biodiversity and degraded ecosystems (Michalak and Ministerial Conference on the Protection of Forests in Europe, 2011). In the U.S., ecological forestry use is unknown, unmeasured, and misunderstood-it can mean "virtually anything" (Batavia and Nelson, 2016; Palik and D’Amato, 2017).

In the face of these ecological challenges for forestry, the U.S. and Europe are taking divergent paths. The North American pursuit of ecological forestry has embraced a natural disturbance paradigm (Seymour et al., 2002) and stresses the importance of forestry goals that are adjusted to local environments and social demands (O'Hara, 2014). As this ecological framework promoting complex solutions advances, however, the U.S. forestry industry does not seem to be adopting its science. Although America is increasingly grasping the importance of forest biodiversity, much of today's practices remain production silviculture that still resemble 19-century European methods (Seymour, 2004; Puettmann et al., 2008). At a national level, the ecological impact of production silviculture on forests should cause concern. For example, global threats from climate change are increasing while U.S. carbon sequestration rates are declining (Houghton, 2003; Birdsey et al., 2006) with projections showing a $35 \%$ decrease in U.S. sequestration rate by 2045 (Wear and Coulston, 2015).

Europe, in contrast, is pursing ecological forestry by a growing trend called Close-to-Nature Forestry (CTNF) requiring low-intensity harvest protocols which continuously protect the forest canopy. Local conditions are considered in an integrated CTNF approach; however, protecting the canopy is prioritized and clear-felling is universally avoided. While having some similarities with U.S. ecological practices, CTNF's broad prioritization of forest canopies has been challenged as a flawed framework that is contrary to forest ecology science (O'Hara, 2015). In spite of this ecological science debate, CTNF is promoted in Europe as ecological forestry and it is gaining a broad adoption. FAO estimates that about 39\% of European forests are in a "modified natural condition" indicating harvest activity with close-to-nature forest dynamics (Ministerial Conference on the Protection of Forests in Europe, 2007). FAO also notes that $80 \%$ of reporting European countries have implemented legal and regulatory frameworks with the most common changes being silvicultural practices for close-to-nature provisions and forest regeneration (Michalak and Ministerial Conference on the Protection of Forests in Europe, 2011). As of 2007, over $98 \%$ of forests in Europe (excluding the Russian Federation) had management plans despite half of European forests being privately owned and $80 \%$ of private forest owners being families or individuals (Ministerial Conference on the Protection of Forests in Europe, 2007). Recently, the European Forest Genetic Resources Program (EUFORGEN) developed a pan-European strategy to conserve forest genetic diversity (COM, 2020) and Forest Europe noted the use of close-to-nature practices to address climate change and forest biodiversity in 21 countries (FOREST EUROPE, 2020).

While their differences are important, the U.S. and European ecological approaches have notable similarities. Both favor lowerintensity methods as higher logging intensity has been shown to cause greater ecosystem degradation; especially to biodiversity (Harmon et al., 1986; Herbeck and Larsen, 1998; Deal et al., 2014; Baker et al., 2016; Kok et al., 2018; Sing et al., 2018), water (Postel and Thompson, 2005; Fiquepron et al., 2013; Sing et al., 2018), and carbon storage (Jandl et al., 2007; Turner et al., 2011). But, although science has guided common development of sustainable practices for forest ecosystems, assessment of those ecosystems has shown that there is "a large gap between the rhetoric and the reality” (Lindenmayer et al., 2012). For forestry, as in other disciplines of ecology, pure science is important, but applied science is what changes ecosystems. And the challenging reality of applied science is that when it is implemented at broad spatial scales and across jurisdictional boundaries, it is primarily influenced, enabled, and approved by non-scientists. As Europe attempts to navigate the challenges of its applied ecological forestry science, it is possible that they are using lowintensity methods too much. Conversely, as America pursues applied ecological forestry science, it appears they may be using too little.

The objective of this perspective is to describe the historical development of ecological forestry in Europe and the United States, and to propose research adjustments to help America pursue broader ecological forestry application and reverse forest ecosystem degradation. By understanding historical precedents that influence forestry perceptions and the differences in contemporary approaches among forestry leaders, forestry scientists may be better equipped to design research and promote practices that change industry behavior for better ecosystem implications.

\section{WHAT IS ECOLOGICAL FORESTRY?}

Ecological forestry is a relatively new concept and one that continues to be debated. Historically, the objectives of silviculture were divergent from those of ecology to the point that some view a new discipline of forest ecology was launched with a textbook published by Stephen Spurr in 1964 (Puettmann et al., 2008). Ecological forestry has been described as a management system with three fundamental principles-retention forestry, 
heterogeneity treatments, and appropriate recovery periods; but at the same time, a discipline that transcends systems, objectives, and settings (Franklin et al., 2007). More recently, ecological forestry has become viewed as retention and disturbancebased management (D’Amato et al., 2017), but even these frameworks can be problematic because the definition and goals of "ecological" have wide conceptual ambiguity in forestry literature (Batavia and Nelson, 2016). To address climate change, some view ecological forestry as making ecosystems adaptable to future environmental changes and not simply being a more "natural" alternative to intensive plantation methods (O'Hara, 2015). Others feel ecological forestry is a comprehensive and practical toolkit to "reduce the divergence between managed and natural ecosystems" (Palik and D'Amato, 2017). The optimization of ecosystem services is yet another emerging framework in ecological forestry with growing popularity, but the causal linkages between biodiversity and ecosystem services are still lacking (Brockerhoff et al., 2017). In the European CTNF trends, terms used under the close-to-nature forestry umbrella include ecologically oriented silviculture, ecologically sound silviculture, and ecologically justified silviculture (Remeš J., 2018). Taken together, the many different ecological forestry systems used in the U.S. and Europe have a range of goal clarity, scientific evidence, and design precision, but all seem to have a stated aspiration of improved ecosystem health while balancing socioeconomic benefits and risks.

When selecting an ecological forestry approach from among the many available options, techniques that engender support, and adoption across broad spatial scales by diverse stakeholders should be given appropriate research and consideration alongside more complicated approaches that may be technically superior. In the U.S., today's innovative set of ecological options have been developed through long-term studies starting from the 1907 establishment of the Harvard Forest where old growth forest research was central to advancing the concept of ecological forestry. Of particular interest was the European Dauerwald system (which can be translated as "continuous forest"), a selection system designed to continuously maintain canopy cover to protect the forest soil (Troup, 1928). Early forestry leaders like Albert Cline and Steven Spurr emphasized a framework similar to Dauerwald, but a wide range of alternative systems have since developed even though low-intensity methods from the early research still remain in the contemporary options (D’Amato et al., 2017). Although subsequent U.S. research shifted to a high-yield, low-cost focus for three decades starting in the 1960's, another shift in the 1990's promoted biodiversity management and fostered natural disturbance frameworks utilizing natural ecological processes (Franklin, 1989, Seymour et al., 2006). Today, numerous U.S. forestry systems have been developed to achieve more natural forests including new forestry, ecosystem management, restoration forestry, ecoforestry, ecological forestry, and near-natural forestry (O'Hara, 2014). Comprehensive site optimizations are increasingly promoted for all options, but this adds complexity and the use of computer models to improve results is growing among advanced practitioners (Diaz-Balteiro and Romero, 2008). Despite the wide variety of options that can be customized
TABLE 1 | The top 30 countries in Europe (excluding the Russian Federation), that account for $98 \%$ of European forests with an indication of whether

Close-to-Nature Forestry is actively used to mitigate the effects of climate change (source: FOREST EUROPE, 2020).

\begin{tabular}{|c|c|c|}
\hline Country & Forest area (million ha) & CTNF use for climate change \\
\hline Sweden & 27.9 & $x$ \\
\hline Finland & 22.1 & $x$ \\
\hline Spain & 17.9 & $x$ \\
\hline France & 15.6 & \\
\hline Germany & 11.1 & $x$ \\
\hline Turkey & 10.2 & $x$ \\
\hline Italy & 10.0 & \\
\hline Ukraine & 9.6 & $x$ \\
\hline Norway & 9.4 & \\
\hline Poland & 9.2 & $x$ \\
\hline Belarus & 8.4 & \\
\hline Romania & 6.4 & \\
\hline Austria & 3.9 & $x$ \\
\hline Portugal & 3.8 & $x$ \\
\hline Greece & 3.8 & \\
\hline Bulgaria & 3.7 & $x$ \\
\hline Latvia & 3.0 & \\
\hline United Kingdom & 2.8 & \\
\hline Georgia & 2.8 & $x$ \\
\hline Czech Republic & 2.6 & $x$ \\
\hline Estonia & 2.3 & \\
\hline Bosnia-Herzegovnia & 2.2 & \\
\hline Croatia & 2.1 & \\
\hline Lithuania & 2.1 & \\
\hline Hungary & 1.9 & $x$ \\
\hline Slovakia & 1.9 & $x$ \\
\hline Serbia & 1.8 & \\
\hline Slovenia & 1.3 & $x$ \\
\hline Switzerland & 1.2 & $x$ \\
\hline Macedonia & 0.9 & \\
\hline
\end{tabular}

Countries arranged by forested area (source: Ministerial Conference on the Protection of Forests in Europe, 2007).

to any location, the extent of ecological forestry use in the U.S. today is essentially unknown or limited to assessment through ecological metrics like the Forest Stewardship Council (FSC) (Palik and D'Amato, 2017) which certifies plantations as ecological.

In Europe, a wide range of ecological practices exist and a growing number are classified under the umbrella term CTNF which requires low-intensity harvests and continuous canopy cover. While CTNF has been challenged by some as a flawed framework that is contrary to forest ecology science (O'Hara, 2015), its adoption exceeds a third of European forests, its utilization for climate change is confirmed by 21 countries (FOREST EUROPE, 2020), and its influence on regulatory or legal provisions is common across Europe (Michalak and Ministerial Conference on the Protection of Forests in Europe, 2011; Table 1). One proponent of CTNF terminology and 
methods is the Pro Silva forestry organization which identifies ecology, conservation, and even restoration as top priorities (Pro Silva Principles, 2012). Participation in this organization has grown to 25 member countries and over 6,000 forester members across Europe. Other users of CTNF seek to mimic natural disturbances, but this is not a standard industry protocol. Sometimes CTNF is characterized as fine-grain uneven-age management or simply as single-tree/small group selection cutting (Schall et al., 2018). Individual member countries of Forest Europe using CTNF for climate change note various definitions, including continuous cover, restoration of natural species, and diversifying of stand structure (FOREST EUROPE, 2020). But the continuous canopy cover and avoidance of clearcutting found in continuous cover forestry (CCF) is becoming nearly synonymous with CTNF (Schütz et al., 2016). The terms CTNF and CCF are often used interchangeably or concomitantly in European forestry literature. When experts summarize forestry systems that fit under CTNF such as Dauerwald (Troup, 1928), Irregular High Forest Management (Susse et al., 2011), Plenter Systems (Schütz et al., 2012), Continuous Cover Forestry (Davies et al., 2008), or Close-to-Nature Forestry (Sanchez, 2013), a predominant theme is almost-absolute-avoidance of clearfelling-largely to maintain permanent canopy cover. Given the importance of ecosystem idiosyncrasies for biodiversity, some proponents of ecology view CTNF's unwavering priority of canopy cover as risky and have critiqued European CTNF as "flawed in its intent" and "poorly grounded in science" (O'Hara, 2015). Despite its flaws and risks vis-à-vis pure science, CTNF has been growing rapidly across Europe for decades (Puettmann et al., 2015; Schütz et al., 2016; Remeš J., 2018).

Many systems fit under the flexible definition of CTNF, however, two features are most common: canopy cover as a primary silvicultural criterion, and typical harvest cycles that are shortened by a factor of 10 . The CTNF canopy cover criterion limits maximum removals of standing volume to 15$20 \%$ for hardwoods or $20-25 \%$ for softwoods, with frequent harvest opportunities to make ecological adjustments: every 57 years for fast tree growth; 7-12 years for slower growth (Sanchez, 2013). CTNF avoids many common techniques of traditional forestry including crop tree identification, rotation length planning, thinning of competing vegetation, removal of pioneer species, and encouragement of extra sunlight by heavier canopy removal (Susse et al., 2011; Sanchez, 2013). In some ways, this reduction of actions and elevation of a consistent goal may be a welcome simplification for the average practitioner; however, to be clear, CTNF is not a system that somehow ignores or forbids ecological silviculture from other systems. All forestry principles and experiences that work well in local conditions should be considered in an integrated CTNF approach; however, protecting the canopy should be prioritized as the default approach and only disregarded when strong ecological evidence suggests otherwise. In cases where site ecology requires heavy canopy removal, CTNF allows a deviation but requires a plan that embraces long-term continuous cover. If a continuous canopy rubric is incorrectly applied to an ecosystem, it can be argued that CTNF is not ecological, but inappropriate application can be a problem of any system. With clear canopy cover protocols, this system provides an ability to define, measure, and audit forest status-preventing the industry's actual practices from becoming virtually anything. In addition, the broad adoption of low-intensity forestry in Europe creates other benefits like a larger market for nimble forestry equipment. Even though low-intensity harvests historically imply increased costs, CTNF continuous cover forestry can be economically competitive with even-age methods (Hanewinkel, 2002; Knoke, 2012; Schütz et al., 2012; O’Hara, 2014; Puettmann et al., 2015).

Many U.S. ecological practices can appear similar to Europe's CTNF: managing for complex multi-aged forest structures, imitating natural processes like disturbances, and prioritizing ecosystem services (O'Hara, 2014). Despite the similarities, however, U.S. forestry science has not pursued research of CTNF or its two most distinctive protocols-continuous canopy cover and frequent light harvests. From a purely scientific perspective, this lack of research is logical. If canopy cover helps ecology for a specific site, the U.S. analytical frameworks should, theoretically, tell you so. Elevating canopy cover in advance of an ecological site assessment seems contrary to science. Unfortunately, the industry does not seem to be following its "better science" and experts suggest that practices branded as ecological are often industrial or virtually anything (Seymour, 2004; Puettmann et al., 2008; Batavia and Nelson, 2016). Despite the persistence of industrial forestry use in the U.S. and CTNF's broad adoption in Europe, the U.S. has largely dismissed the potential advantages that could exist in the European trend. Historical research and conclusions play a role in this position as American forestry resists low-intensity methods due to the risk of fixed-diameter limit cutting (Brissette et al., 2006) or "high-grading" (O'Hara, 1998; Seymour, 2004; Evans and Perschel, 2009) as well as the risk of potential shifts toward shade-tolerant regeneration cited by both the U.S. and Europe (Seymour, 2004; Bauhus et al., 2013; Ligot et al., 2014; O’Hara, 2014; Puettmann et al., 2015). In addition, U.S. foresters can strongly defend clear-cutting as an important forestry tool. Whether these positions are based on ecological studies or economic influences formed under different historical contexts is unclear. But in the current context of climate trends demanding more from forest ecosystems, the absence of serious consideration of low-intensity frameworks growing rapidly in Europe seems to be an odd omission.

\section{HISTORICAL BARRIERS}

In the early 1800 's, U.S. lumber consumption, farm clearing, and fuelwood use grew rapidly as industries experienced technical innovations and the country sustained a westward expansion. By 1872, public officials warned of a "timber famine." The dire warnings continued into the 1900s to include even the president, Theodore Roosevelt. Reacting to devastated landscapes, Congress entertained over 200 bills related to forestry between 1870 and 1900 (Williams, 1989). An early step, The Forest Reserve Act of 1891, enabled the creation of forest reserves protected by the U.S. Government. By 1897, 20 reserves had been established protecting 15 million hectares and The Organic Act of 1897 provided statutory framework for managing those reserves. 
Then, a sudden shift occurred. As fossil fuel consumption grew 17-fold between 1850 and 1955, the role of wood as a national fuel source dropped from 90 to 5\% (Williams, 1989). From 1910 to 1959, America became less agrarian so nearly 0.4 million forest hectares were added annually from abandoned farmland (Williams, 1989, 2006). Along with this growth of the nation's timberlands, ecological expectations increased with Aldo Leopold's A Sand County Almanac in 1949 and Rachel Carson's Silent Spring in 1962. Ecological legislation expanded to include the Multiple-Use and Sustained Yield Act of 1960, the Clean Air Act of 1963, the Wilderness Act of 1964, the National Environmental Policy Act of 1969, the Clean Water Act of 1972, and the National Forest Management Act of 1976. During the 1970's and 1980's, ecology's goal of "sustainable management" changed to "ecosystem management" as care of lands and forests embraced even higher aspirations. With a positive step in 1992, the US Forestry Service formally adopted ecosystem management as a more holistic approach to forestry (Williams, 2005).

Despite legislation and public sentiment, the practice of forestry responded slowly. Although today forest biodiversity is well-understood in the U.S., forestry practices are still similar to those used in the early 1900's (Puettmann et al., 2008): simplifying forests and causing declines in biodiversity and carbon stocks (Lindenmayer et al., 2012; Batavia and Nelson, 2016; Franklin et al., 2018). This bleak assessment is not from a lack of willingness or effort on the part of forestry professionals. In the early 1930's, roughly 30 years after America established its first college-level forestry schools, the U.S. Forestry Service (USFS) denounced universally-practiced clear-cutting. In its place, USFS embraced selection cutting which was developing in Europe. After pursuing selection cutting for three decades, however, USFS deemed it unsuccessful and abandoned it in 1960 (Seymour, 2004). The new direction required "multiple-use" forestry which employs even-aged silviculture with moderate-sized, dispersed clear-cut blocks and is legislatively supported by the Multiple-Use and Sustainable Yield Act of 1960 (Curtis, 1998; Seymour, 2004). Historians now assess the selective cutting policy mandated in the 1930's as poorly implemented and driven by economics (Curtis, 1998). Regardless of reasons, selection cutting has remained a largely condemned practice while extensive promotion of clear-cutting "stifled research into other silvicultural systems for decades” (Curtis, 1998; Puettmann et al., 2008).

Assessments of America's forestry evolution are not without debate. Experts staunchly defend multiple-use frameworks which are based on landowner objectives. Effectively, this framework requires a relatively neutral role of the forester (whose practical alternatives are defined by the local industry) while the landowner controls his harvests without undue interference. Unfortunately, economics tends to dominate-especially for private owners who hold $58 \%$ of U.S. forests (Oswalt et al., 2019). Nearly $60 \%$ of private forestlands are family-owned but the awareness of ecological forestry among this group seems weak given that $<13 \%$ of family forestland owners had a written management plan in 2017 (Oswalt et al., 2019). Without an active promotion of ecological forestry options that can achieve good economics and ecosystem service value, decisions naturally perpetuate past practices. Measurements of ecological forestry exist, but many systems certify plantations as ecological. Meanwhile, government-owned forests in the U.S. totaled 59 million hectares in 1910 and expanded to 126 million hectares today. So, elevating ecology in a majority of American forestland should have been attainable. Instead, the ecological status of America's forests is perplexing.

For Europe, historical challenges were similar to those in America; however, independent political structures and more time fostered different solutions. For many centuries, growing populations consumed forests for fuel and agriculture, but the requirements for shipbuilding, charcoal burning, and ironmaking in the 1500's and 1600's are what devastated European forests. After the 1713 enactment of Saxony's Silvicultura Oeconominca, the 1769 establishment of the Forest Order in the Austrian Monarchy, and the 1792 founding of Frieberg University's forestry school, sustainable forestry became a common practice. The German forest system was the benchmark of optimizing yield, sustainability, and economics. Compared to prior unsustainable deforestation, Freiberg's research brought disciplined rotation of clear-cut harvests, artificial regeneration, and engineering optimization that became a sign of properly managed forests. During the period from 1740 to 1897 , this approach was implemented throughout Germany with economic responsiveness that shifted conifer composition from 50 to $90 \%$ nationally (Diaci, 2006). The success of German forestry prompted other countries to institute laws, like France's Forest Law of 1827, to prohibit primitive methods like selective single stem harvesting. But amid the German forestry success, influential voices promoted much more ecological approaches. Within Germany, Julius Ernst von Schütz argued in 1757 against clear-felling as too damaging to soil conservation and forest regeneration. Schütz suggested the best regeneration results were achieved under continuous canopy cover; however, his approach was heavily criticized. Around 1880, the French Forest Officer Adolphe Gurnaud developed an approach called "continuous renewal" where the German practice of "harvests at optimum rotation age" was abandoned (Schütz et al., 2012). Instead, Gurnaud utilized continuous single tree selective cutting controlled by stand conditions and individual tree growth rates. Gurnaud's ideas met strong resistance (including in his own French forest administration), but proponents of his methods emerged. A staunch supporter was Henri Biolley, a Swiss district forester, who formalized Gurnaud's approach into a comprehensive system. Biolley's system was broadly adopted and is respected for its influence to this day. Since Germany and Austria had many small states with decentralized administration and legislation, different forestry approaches developed in the various administrative regions (Diaci, 2006). With diverse site characteristics from the Alps to the surrounding lowlands, forestry methods disallowing clearcutting and promoting complex structures developed for many situations. In some cases, these requirements were necessary to protect villages from avalanches, but many environments showed ecological and economic benefits. Switzerland was the first country to prohibit clear-cut forest management by law in 1902 and Slovenia followed with a similar ban in 1948 (Diaci, 2006). Regions in Central Europe developed a "back to 
nature" approach with primarily ecological objectives in the late 1800 's. Over the last 200 years, Europe has primarily followed the German forestry model, but close-to-nature systems also flourished. While specific regions may have waxed and waned in their preferred approaches, Europe did not see the swing to extremes that the U.S. experienced with their national adoption and then abandonment of selection cutting in the 1930's and 1960 's, respectively. At least partially due to its administrative fragmentation, Europe sustained a wide variety of ecological practices. In the last three decades, many European approaches have been growing in acceptance under the CTNF name and under the leadership of organizations like Pro Silva. Since 1993 France alone has established 81 forest research stations dedicated to CTNF and spanning a wide variety of forest types and site conditions (Susse et al., 2011).

Today, the global need for ecological forestry is more important than ever (Williams, 2006; Lindenmayer et al., 2012; Franklin et al., 2018). Although experts around the world have advanced the pure science of ecological forestry over the last century, the applied science is still struggling. In the midst of disappointing global progress, however, Europe seems to have achieved a breakthrough in application, in part, by promoting low-intensity methods and canopy cover. If this simplified lowintensity approach is significantly inappropriate across ecosystem types, it seems like Europe has placed a bad bet. If canopy cover is an ecologically reasonable gamble, however, it seems like the European approach might enable changed behavior in other regions where it can then be fine-tuned for even better ecology without uncritical overuse. An important next step to answer this question is to assess the ecological implications of continuous canopy cover.

\section{ECOSYSTEM IMPLICATIONS}

Since the time of the Harvard Forest, old growth forests have been a key benchmark for assessing and modeling ecosystem health of a forest (D'Amato et al., 2017). Different metrics have been applied to forest health over the decades and one of the more comprehensive frameworks for evaluating forest ecology is the concept called ecosystem services. Forest ecosystem services include functions like carbon storage, biodiverse habitats, watershed regulation, soil nutrient cycling, cultural recreation, and timber products (De Groot et al., 2002; Brockerhoff et al., 2017; Sing et al., 2018). Comparing different sites historically or prospectively is challenging, however, because not all ecosystem services can be simultaneously maximized, and priority values may differ among stakeholders. The benchmark for natural forest development is old growth forests, but even the term "old growth" can have many meanings. The most common criteria in ecological forestry for old growth systems is stand age (i.e., $150+$ years-old), complex canopy, coarse woody debris, and a few old trees near maximum longevity (i.e., 300+ years; Carey and Johnson, 1995; Oliver and Larson, 1996; Herbeck and Larsen, 1998; Mosseler et al., 2003; Rapp, 2003). A key ecological health metric relative to old growth forests is biodiversity, but because ecological forestry requires different solutions across multiple scales, assessing its overall impact on biodiversity is a difficult task (Bunnell and Huggard, 1999; Bergeron and Fenton, 2012; Nolet et al., 2017). In North America, traditional forestry has been the norm for centuries, confounding attempts to make direct and controlled comparisons of management influences on biodiversity in old growth, mature second growth, and newly cut forests (Hansen et al., 1991; Sullivan et al., 2001; Mossman et al., 2019). These historically-constrained comparisons of forest biodiversity in North America can be instructive, however, as studies in Washington, Oregon, California, Missouri, and Ontario, Canada (Harmon et al., 1986; Welsh, 1990, Herbeck and Larsen, 1998; Jung et al., 1999; Forsman et al., 2016) have reported dramatically higher species richness and abundance values for select species in old growth forests when compared to newly cut forests. More controlled comparisons of ecological forest management practices on biodiversity are possible in Europe due to forestry's historical development there. Schall et al. (2018) studied the impacts of uneven-aged, even-aged, and unmanaged forest management practices on biodiversity in a $400 \mathrm{~km}^{2}$ region of deciduous forests in central Germany where continuous cover forestry methods had been used for well over a century. While the study's conclusion determined that even-aged methods in these forests achieved better landscape biodiversity than uneven-aged, the ecosystem response was very positive to both methodsshowing similar or better biodiversity status for managed forests compared to unmanaged forests in this region. Furthermore, the study concluded that the best landscape biodiversity resulted from low-intensity practices-both the even-age (small patch) forest management and CTNF methods studied were classified as continuous cover forestry. In addition, Paillet et al. (2010) reviewed nearly 50 studies of European forests and concluded that forests under intensive management practices had lower species richness.

While an exhaustive review of the benefits of canopy cover is beyond the scope of this perspective, we note that several habitat characteristics that have been linked to biodiversity in old growth forests-canopy cover, moisture, temperature, and woody debris-are conditions that are promoted in continuous canopy forests. Within forests, microclimates are highly sensitive to overstory canopy (Hungerford and Babbitt, 1987; Chen and Franklin, 1997). Greater extremes in temperature, wind, and desiccation occur at harvested structural boundaries like patches or canopy reductions and can extend into the forest by four to six tree heights (Laurance et al., 1997; Chen et al., 1999). Chen et al. (1999) also showed that temperature-overstory microclimate relationships within stands expand their influence and combine with roads or topographical variations to influence microclimates at landscape scales. The implications of these studies are that, while canopy cover is not a guarantee of improved biodiversity or absence of silvicultural risks, continuous canopy cover often improves ecosystem health compared to the use of higherintensity practices of traditional forestry. Understanding the true risk of broadly-applied canopy cover, therefore, should attempt to maximize canopy benefits and mitigate its risk with management techniques. Future research should include the landscape level biodiversity impact from canopy-prioritizing systems applied in different types of forests, the long-term effects of small-gap 
management with mitigation techniques, and the influence of stand age on silvicultural and economic results when using canopy-prioritized low-intensity approaches.

\section{CONCLUSION}

Over the last two centuries, the science of forestry has steadily increased its emphasis on ecology with innovative leadership from Europe and America. Despite the many advancements, however, the world's collective forest ecosystem management is still weak at a time when carbon levels are rising, and biodiversity is at risk. The disappointing status of forests is caused less by insufficient forestry innovation and more by insufficient adoption of ecological practices across the industry. Innovation in U.S. ecological forestry is strong, but the common industry practice is still virtually anything and largely driven by historical precedent. Europe is pursuing an ecological approach with scientific flaws, but that movement is showing the kind of broad adoption in Europe that could help others protect forest biodiversity. To drive needed change in the pursuit of ecological forestry, however, science needs to influence many non-scientists: the logger, the sawmill owner, the equipment manufacturer, the TIMO (Timber Investment Management Organization) manager, the landowner, the politician, the voter, and the student. Many of these stakeholders support the concept of ecology, but they need to understand what concrete actions they can take-and the implications of these actions-in order for them to change their behavior. In Europe, the call for action is clear: "protect the forest canopy." In the U.S., the message of forest ecology requires flexibility for the uncertainty of each case. The call for action becomes: "it depends." If the simple directive "protect the forest canopy unless other circumstances dictate" is repeated, then stakeholders may be more widely and clearly equipped to change behaviors and make longer-term commitments.

Given the risk that such a directive may be over-applied, the goal of scientific research must pivot to defining the conditions

\section{REFERENCES}

Baker, S. C., Halpern, C. B., Wardlaw, T. J., Kern, C., Edgar, G. J., Thomson, R. J., et al. (2016). A cross-continental comparison of plant and beetle responses to retention of forest patches during timber harvest. Ecol. Appl. 26, 2495-2506. doi: 10.1002/eap.1406

Batavia, C., and Nelson, M. P. (2016). Conceptual ambiguities and practical challenges of ecological forestry: a critical review. J Forestry 114, 572-581. doi: 10.5849/jof.15-103

Bauhus, J., and Puettmann, K. J., Kuhne, C. (2013). "Close-to-nature forest management in Europe" in Managing Forests as Complex Adaptive Systems, eds C. Messier, K. J. Puettmann, and K. D. Coates (Routledge), 187-213.

Bergeron, Y., and Fenton, N. J. (2012). Boreal forests of eastern canada revisited: old growth, nonfire disturbances, forest succession, and biodiversity. Botany 90, 509-523. doi: 10.1139/b20 12-034

Birdsey, R., Pregitzer, K., and Lucier, A. (2006). Forest carbon management in the United States: 1600-2100. J. Environ. Qual. 35, 1461-1469. doi: $10.2134 /$ jeq2005.0162

Brissette, J. C., Saunders, M. R., and Kenefic, L. S. (2006). Long-term research on classical silvicultural approaches in the acadian forest: penobscot experimental where canopy protection may increase ecological risk to an unacceptable level. As CTNF sweeps through Europe, for the US not to be pushing serious evaluation of this broadly-adopted practice from leadership levels like the USFS and universitybased forestry programs is a concerning omission. The U.S. needs to expand its pursuit of ecological forestry, and U.S. forestry experts need to promote a more actionable call to America's stakeholders. To do this, the U.S. needs to seriously experiment with the newest European methods despite the temptation of saying "we have done that before." Historical paradigms that protect and promote clear-cutting and high intensity methods should be critically evaluated. Metrics that classify plantations as eco-friendly approaches should be scrutinized. While it is possible that Europe is applying continuous cover objectives too broadly today, it is also possible that the U.S. is inappropriately dismissing continuous cover and its clear and easily communicated call for action.

\section{DATA AVAILABILITY STATEMENT}

The original contributions presented in the study are included in the article/supplementary material, further inquiries can be directed to the corresponding author/s.

\section{AUTHOR CONTRIBUTIONS}

JG conceptualized the idea for the paper and drafted the primary manuscript. JC contributed formative feedback and edits and helped identify a suitable publication outlet. All authors contributed to the article and approved the submitted version.

\section{FUNDING}

The Herbert W. Hoover Foundation (https://www. hwhfoundation.org/) provided grant support to cover the processing fee of this article. forest part I. ResearchGate 239921494. Available online at: https://www.fs.usda. gov/treesearch/pubs/13188

Brockerhoff, E. G., Barbaro, L., Castagneyrol, B., Forrester, D. I., Gardiner, B., González-Olabarria, J. R., et al. (2017). Forest biodiversity, ecosystem functioning and the provision of ecosystem services. Biodiversity Conserv. 26, 3005-3035. doi: 10.1007/s10531-017-1453-2

Bunnell, F. L., and Huggard, D. J. (1999). Biodiversity across spatial and temporal scales: problems and opportunities. Forest Ecol. Manag. 115, 113-126. doi: 10.1016/S0378-1127(98)00392-2

Carey, A. B., and Johnson, M. L. (1995). Small mammals in managed, naturally young, old-growth forests. Ecol. Appl. 5, 336-352. doi: 10.2307/1942026

Chen, J., and Franklin, J. F. (1997). Growing-season microclimate variability within an old-growth douglas-fir forest. Clim. Res. 8, 21-34. doi: 10.3354/cr008021

Chen, J., Saunders, S. C., Crow, T. R., Naiman, R. J., Brosofske, K. D., Mroz, G. D., et al. (1999). Microclimate in forest ecosystem and landscape ecology. BioScience 49, 288-297. doi: 10.2307/1313612

COM (2020). Communication From the Commission to the European Parliament, the Council, the European Economic and Social Committee and the Committee of the Regions. EU Biodiversity Strategy for 2030. Brussels.

Curtis, R. O. (1998). Selective cutting in douglas-fir - history revisited. J. Forestry $96,40-46$. 
D’Amato, A. W., Palik, B. J., Franklin, J. F., and Foster, D. R. (2017). Exploring the origins of ecological forestry in North America. J. Forestry 115, 126-127. doi: $10.5849 /$ jof.16-013

Davies, O., Haufe, J., and Pommerening, A. (2008). Silvicultural Principles of Continuous Cover Forestry: A Guide to Best Practice. Bangor: Bangor University and Forestry Commission Wales.

De Groot, R., Boumans, R., and Wilson, M. (2002). A typology for the classification description and valuation of ecosystem functions, goods and services. Ecol. Econ. 41, 393-408. doi: 10.1016/S0921-8009(02)00089-7

Deal, R. L., Hennon, P., O'Hanlon, R., and D'Amore, D. (2014). Lessons from native spruce forests in alaska: managing sitka spruce plantations worldwide to benefit biodiversity and ecosystem services. Forestry 87, 193-208. doi: 10.1093/forestry/cpt055

Diaci, J. (2006). Nature-Based Forestry in Central Europe - Alternatives to Industrial Forestry and Strict Preservation. Ljubljana: Biotechnical Facility, University of Ljublijana.

Diaz-Balteiro, L., and Romero, C. (2008). Making forestry decisions with multiple criteria: a review and an assessment. Forest Ecol. Manage. 255, 3222-41. doi: 10.1016/j.foreco.2008.01.038

Evans, A. M., and Perschel, R. (2009). A review of forestry mitigation and adaptation strategies in the Northeast U.S. Clim Change. 96, 167-183. doi: 10.1007/s10584-009-9569-3

Fiquepron, J., Garcia, S., and Stenger, A. (2013). Land use impact on water quality: valuing forest services in terms of the water supply sector. J. Environ. Manage. 126, 113-121. doi: 10.1016/j.jenvman.2013.04.002

FOREST EUROPE (2020). Adaptation to Climate Change in Sustainable Forest Management in Europe, Liaison Unit Bratislava. Zvolen.

Forsman, E. D., Swingle, J. K., Davis, R. J., and Biswell, B. L. (2016). Tree Voles: An Evaluation of Their Distribution and Habitat Relationships Based on Recent and Historical Studies, Habitat Models, Vegetation Change. USFS General Technical Report PNW-GTR-948. Portland, OR. doi: 10.2737/PNW-GTR-948

Franklin, J. F. (1989). The 'New Forestry.' J. Soil Water Conserv. 44:549.

Franklin, J. F., Johnson, K. N., and Johnson, D. L. (2018). Ecological Forest Management. Long Grove, IL: Waveland Press, Inc.

Franklin, J. F., Mitchell, R. J., and Palik, B. J. (2007). Natural Disturbance and Stand Development Principles for Ecological Forestry. Newtown Square, PA: U.S. Department of Agriculture, Forest Service, Northern Research Station. doi: $10.2737 /$ NRS-GTR-19

Hanewinkel, M. (2002). Comparative economic investigations of even-aged and uneven-aged silvicultural systems: a critical analysis of different methods. Forestry 75, 473-481. doi: 10.1093/forestry/75.4.473

Hansen, A. J., Spies, T. A., Swanson, F. J., and Ohmann, J. L. (1991). Conserving biodiversity in managed forests. BioScience 41, 382-392. doi: 10.2307/1311745

Harmon, M. E., Anderson, N. H., Franklin, J. F., Cline, S. P., Swanson, F. J., Aumen, N. G., et al. (1986). Ecology of coarse woody debris in temperate ecosystems. USDA Forest Serv. 15, 133-302. doi: 10.1016/S0065-2504(08)60121-X

Herbeck, L. A., and Larsen, D. (1998). Plethodontid salamander response to silvicultural practices in Missouri Ozark Forests. Conserv. Biol. 13, 623-632. doi: 10.1046/j.1523-1739.1999.98097.x

Houghton, R. A. (2003). Revised Estimates of the Annual Net Flux of Carbon to the Atmosphere from Changes in Land Use and Land Management 1850-2000. EBSCO Publishing. doi: 10.1034/j.1600-0889.2003.01450.x

Houghton, R. A., Hobbie, J. E., Melillo, J. M., Moore, B., Peterson, B. J., Shaver, G. R., et al. (1983). Changes in the carbon content of terrestrial biota and soils between 1860 and 1980: a net release of CO " 2 to the atmosphere. Ecol. Monographs 53, 235-262. doi: 10.2307/1942531

Hungerford, R. D., and Babbitt, R. E. (1987). "Overstory removal and residue treatments affect soil surface, air, soil temperature," USDA Forest Service Research Paper INT-377. Ogden, UT. doi: 10.5962/bhl.title.68876

Jandl, R., Lindner, M., Vesterdal, L., Bauwens, B., Baritz, R., F., Hagedorn, F., et al. (2007). How strongly can forest management influence soil carbon sequestration? Geoderma 137, 253-68. doi: 10.1016/j.geoderma.2006.09.003

Jung, T. S., Thompson, I. D., Titman, R. D., and Applejohn, A. P. (1999). Habitat selection by forest bats in relation to mixed-wood stand types and structure in Central Ontario. J. Wildlife Manag. 63:1306. doi: 10.2307/3802849

Knoke, T. (2012). "Continuous cover forestry - chapter 5: the economics of continuous cover forestry," in Managing Forest Ecosystems, Vol. 23, eds T.
Pukkala and K. von Gadow (Dordrecht: Springer Netherlands), 167-193. doi: 10.1007/978-94-007-2202-6_5

Kok, M. T. J., Alkemade, R., Bakkenes, M., van Eerdt, M., Janse, J., Mandryk, M., et al. (2018). Pathways for agriculture and forestry to contribute to terrestrial biodiversity conservation: a global scenariostudy. Biol. Conserv. 221, 137-150. doi: 10.1016/j.biocon.2018.0 3.003

Laurance, W. F., Gascon, C., Bierregaard, R., Didham, R., Smith, A. P., Lynam, A. J., et al. (1997). "Tropical forest fragmentation: synthesis of a diverse and dynamic discipline," in: Tropical Forest Remnants: Ecology, Management, and Conservation of Fragmented Communities, eds W. F. Laurance, and R. O. Jr. Bierregaard (Chicago, IL: University of Chicago Press). 502-514.

Ligot, G., Balandier, P., Courbaud, B., Jonard, M., Kneeshaw, D., and Claessens, H. (2014). Managing understory light to maintain a mixture of species with different shade tolerance. Forest Ecol. Manage. 327, 180-200. doi: 10.1016/j.foreco.2014.05.010

Lindenmayer, D. B., Franklin, J. F., Lõhmus, A., Baker, S. C., Bauhus, J., Beese, W., et al. (2012). A major shift to the retention approach for forestry can help resolve some global forest sustainability issues: retention forestry for sustainable forests. Conserv. Letters 5, 421-431. doi: 10.1111/j.1755-263X.2012.00257.x

Michalak, R., and Ministerial Conference on the Protection of Forests in Europe (eds.). (2011). State of Europeś Forests 2011: Status and Trends in Sustainable Forest Management in Europe. Forest Europe Growing Life. Oslo: Ministerial Conference on the Protection of Forests in Europe.

Ministerial Conference on the Protection of Forests in Europe (ed.). (2007). State of Europe's Forests 2007: The MCPFE Report on Sustainable Forest Management in Europe. Warsaw: Ministerial Conference on the Protection of Forests in Europe.

Mosseler, A., Thompson, I., and Pendrel, B. (2003). Overview of old-growth forests in Canada from a science perspective. Environ. Rev. 11, S1-S7. doi: 10.1139/a03-018

Mossman, A., Lambert, M. R., Ashton, M. S., Wikle, J., and Duguid, M. C. (2019). Two salamander species respond differently to timber harvests in a managed New England Forest. PeerJ 7:e7604. doi: 10.7717/peerj.7604

Nolet, P., Kneeshaw, D., Messier, C., and Beland, M. (2017). Comparing the effects of even- and uneven-aged silviculture on ecological diversity and processes: a review. Ecol. Evol. 8, 1217-1226. doi: 10.1002/ece3.3737

O’Hara, K. L. (1998). Silviculture for structural diversity: a new look at multi-aged systems. J. Forestry $96,4-10$.

O'Hara, K. L. (2014). Multiaged Silviculture - Managing for Complex Forest Stand Structures. Croydon: Oxford University Press. doi: 10.1093/acprof:oso/9780198703068.001.0001

O'Hara, K. L. (2015). What is close-to-nature silviculture in a changing world? Forestry 89, 1-6 doi: 10.1093/forestry/cpv043

Oliver, C. D., and Larson, B. C. (1996). Forest Stand Dynamics. New York, NY: John Wiley \& Sons.

Oswalt, S. N., Smith, W. B., Miles, P. D., and Pugh, S. A. (2019). Forest Resources of the United States, 2017: A Technical Document Supporting the Forest Service 2020. RPA Assessment. Washington, DC: U.S. Department of Agriculture, Forest Service. doi: 10.2737/WO-GTR-97

Paillet, Y., Bergès, L., Hjältén, J., Ódor, P., Avon, C., Bernhardt-Römermann, M., et al. (2010). Biodiversity differences between managed and unmanaged forests: meta-analysis of species richness in Europe. Conserv. Biol. 24, 101-112. doi: 10.1111/j.1523-1739.2009.01399.x

Palik, B. J., and D'Amato, A. W. (2017). Ecological forestry: much more than retention harvesting. J. Forestry 115, 51-53. doi: 10.5849/jof.16-057

Postel, S. L., and Thompson, B. H. (2005). Watershed protection: capturing the benefits of nature's water supply services. Nat. Res. Forum 29, 98-108. doi: 10.1111/j.1477-8947.2005.00119.x

Pro Silva Principles (2012). Association of European Foresters Practising Management Which Follows Natural Processes. PRO SILVA.

Puettmann, K. J., Coates, K. D., and Messier, C. (2008). A Critique of Silviculture: Managing for Complexity. Washington, DC: Island Press, 27-28.

Puettmann, K. J., McWilson, S., Baker, S. C., Donoso, P. J., Drössler, L., Amente, G., et al. (2015). Silvicultural alternatives to conventional evenaged forest management - what limits global adoption? Forest Ecosyst. 2:8. doi: 10.1186/s40663-015-0031-x 
Rapp, V. (2003). New Findings About Old-Growth Forests. USFS Science. No. 4. Portland, OR: US Department of Agriculture, Forest Service, Pacific Northwest Research Station.

Remeš J. (2018). Development and present state of close-to-nature silviculture. J. Landscape Ecol. 11, 17-32. doi: 10.2478/jlecol-2018-0010

Sanchez, C. (2013). Pro Silva Silviculture Guidelines on Continuous Cover Forestry/Close to Nature Management Practices. Forêt Wallone 7-9, 13, 30. Available online at: https://prosilva.fr/files/brochures/brochure_infoProSilva. pdf

Schall, P., Gossner, M. M., Heinrichs, S., Fischer, M., Boch, S., Prati, D., et al. (2018). The impact of even-aged and uneven-aged forest management on regional biodiversity of multiple taxa in european beech forests. edited by Akira Mori. J. Appl. Ecol. 55, 267-278. doi: 10.1111/1365-2664.12950

Schütz, J. P., Pukkala, T., Donoso, P. J., and von Gadow, K. (2012). "Historical emergence and current application of CCF," in Continuous Cover Forestry. Managing Forest Ecosystems, Vol. 23, eds T. Pukkala, and K. von Gadow (Dordrecht: Springer). doi: 10.1007/978-94-007-2202-6_1

Schütz, J. P., Saniga, M., Diaci, J., and Vrška, T. (2016). Comparing close-to-nature silviculture with processes in pristine forests: lessons from central Europe. Ann. Forest Sci. 73, 911-921. doi: 10.1007/s13595-016-0579-9

Seymour, R. S. (2004). "Silviculture: lessons from our past, thoughts about the future," in Proceedings of the Great Lakes Silviculture Summit. General Technical Report NC-254, eds B. Palik and L. Levy (St. Paul, MN: U.S. Department of Agriculture, Forest Service, North Central Forest Experiment Station), 5-14. Available online at: https://www.srs.fs.usda.gov/pubs/19057

Seymour, R. S., Guldin, J., Marshall, D., and Palik, B. (2006). Large-scale, longterm silvicultural experiments in the United States: historical overview and contemporary examples. Allgemeine Forst und Jagdzeitung. 177, 104-112. Available online at: https://www.fs.usda.gov/treesearch-beta/pubs/27232

Seymour, R. S., White, A. S., and deMaynadier, P. G. (2002). Natural disturbance regimes in Northeastern North America-evaluating silvicultural systems using natural scales and frequencies. Forest Ecol. Manage. 155, 357-67. doi: 10.1016/S0378-1127(01)00572-2

Sing, L., Metzger, M. J., Paterson, J. S., and Ray, D. (2018). A review of the effects of forest management intensity on ecosystem services for Northern European temperate forests with a focus on the UK. Forestry 91, 151-164. doi: $10.1093 /$ forestry/cpx 042
Sullivan, T. P., Sullivan, D. S., and Lindgren, P. M. E. (2001). Stand structure and small mammals in young lodgepole pine forest: 10-year results after thinning. Ecol. Appl. 11, 1151-1173. doi: 10.1890/1051-0761(2001)0111151:SSASMI2.0.CO;2

Susse, R., Allegrini, C., Bruciamacchie, M., and Burrus, R. (2011). Management of irregular forests. Assoc. Futaie Irrégulière. 3, 25-31, 57,87. Available online at: https://www.ccfg.org.uk/wp-content/uploads/2017/08/news_Management_ of_Irregular_Forests.pdf

Troup, R. S. (1928). Silvicultural Systems. London: Amen House.

Turner, D. P., Ritts, W. D., Yang, Z., Kennedy, R. E., Cohen, W. B., Duane, M. V., et al. (2011). Decadal trends in net ecosystem production and net ecosystem carbon balance for a regional socioecological system. Forest Ecol. Manage. 262, 1318-1325. doi: 10.1016/j.foreco.2011.06.034

Wear, D. N., and Coulston, J. W. (2015). From sink to source: regional variation in U.S. Forest Carbon Futures. Sci. Rep. 5:16518. doi: 10.1038/srep 16518

Welsh, H. H. (1990). Relictual amphibians and old-growth forests. Conserv. Biol. 4, 309-319. doi: 10.1111/j.1523-1739.1990.tb00293.x

Williams, G. W. (2005). The USDA Forest Service - The First Century. Washington, DC: USDA Forest Service Office of Communication.

Williams, M. (1989). Americans \& Their Forests - A Historical Geography. Cambridge; New York, NY: Cambridge University Press.

Williams, M. (2006). Deforesting the Earth - From Prehistory to Global Crisis. Chicago, IL: The University of Chicago Press. doi: 10.7208/chicago/9780226899053.001.0001

Conflict of Interest: The authors declare that the research was conducted in the absence of any commercial or financial relationships that could be construed as a potential conflict of interest.

Copyright (๑) 2021 Gresh and Courter. This is an open-access article distributed under the terms of the Creative Commons Attribution License (CC BY). The use, distribution or reproduction in other forums is permitted, provided the original author(s) and the copyright owner(s) are credited and that the original publication in this journal is cited, in accordance with accepted academic practice. No use, distribution or reproduction is permitted which does not comply with these terms. 